\title{
AMATEUR ART AND CONTEMPORARY REGIONAL IDENTITY \\ A CASE STUDY OF POLISH SPISZ ${ }^{1}$
}

\section{JANUSZ BARANSKI}

The subject of this article is the role of a certain form of amateur art by the local sculptor Stanistaw Burkat during transformations in the regional identity of the residents of Poland's Spisz region (Slovak: Spiš).

Keywords: legend, Janošik, amateur art, sculptor
$V$ razpravi avtor obravnava vlogo amaterske umetnosti lokalnega kiparja Stanisława Burkatav med transformacijo regionalne identitete prebivalcev poljske pokrajine Spisz (slovaško: Spiš).

Ključne besede: legenda, Janošik, amaterska umetnost, kipar

The subject of this article is the role of a certain form of amateur art by the local sculptor Stanisław Burkat during transformations in the regional identity of the residents of Poland's Spisz region (Slovak: Spiš). The majority of this geographical and, at the same time, cultural region is located in Slovakia, and only a small part is in Poland. The author discusses the Polish part of this region, which, as a result of nearly a century of its inclusion in Poland, has acquired a slightly different political, economic, and social character (formerly, the entire region belonged to the Kingdom of Hungary). Nonetheless, both the residents of this transborder region and those studying it can easily list certain shared elements with Slovak Spiš in terms of its language, customs, folklore, and material culture. This is also true regarding the regional mythology, which includes the legend of Juraj Jánošík, a local cultural hero whose origin has over time become an object of dispute between the Poles and Slovaks.

The mythological dimension of this character is mainly limited to his ascribed role as a bandit that robbed the rich and helped the poor, much like (among others) Robin Hood; hence, his status is that of a cultural hero. Historically speaking, Jánošík was a real person. He was a Slovak that lived in the seventeenth and eighteenth centuries, and was sentenced to death for his criminal activities. No historical evidence exists that Jánošík ever lived within the area of contemporary Poland. However, the borderland character of Spisz has also made him, by force of totum pro parte, the hero of much recent mythology on the Polish side of the border. For instance, the tour guides at Niedzica Castle, the unofficial capital of Polish Spisz, relate a legend that Jánošík was once imprisoned there (showing the tourists a rock he was chained to). According to another legend told by Michał Balara, a popularizer of folk culture, Jánošík, when travelling as he was wont to do from Poland to

1 This project was financed by the National Science Center under decision no. DEC-2013/09/B/HS3/03590. 
Spisz, once jumped across the Dunajec River like a feather. Ever since that time, the narrowest point of the Dunajec has been called Janosików Skok 'Jánošík's Jump' (2013: 33).

This and other content that concerns the border region's national hero and situates his activities according to the requirements of the regional — and sometimes national—poetic license suffices to explain a certain type of garden decoration, which is displayed next to some houses and is often noticed by visitors to Polish Spisz, especially to Niedzica. Among the green bushes and colorful flowers, sometimes in a gazebo designed specifically for this purpose, or sometimes alongside universal, "interregional" decorations (e.g., gnomes, deer, and mushrooms), there rests the small figure of a peculiar and yet strangely familiar man (Figure 1). A walk through the village would certainly lead one to the conclusion that every figurine was made by the same artist, as is evidenced by the similarities in terms of their material, technique, style, choice of colors, and (most importantly) theme.

The taxonomy of sculptural art is a tool that may fail to indicate the genre of art dealt with here, even for art historians and ethnographers that are used to atypical forms of creative expression. This is a character whose special form resembles a human sculpture, but cannot be attributed as such in its entirety because the sculptural element is present almost solely in the figurine's schematically outlined face. The face is occupied by a prominent nose and large almond-shaped eyes with iris-less pupils that visually accentuate the whites of the eyes, which are surrounded by ray-like eyelashes. It also has bright red lips and sometimes brown facial hair. This representation of a face is both terrifying and grotesque, or is at least very expressive. A certain layer of aesthetic values dictates that the sculpture be placed within the genre of art brut, although other elements shift it more toward the area of naive and non-professional art, and it is in no manner detached from the content of the local culture (see below). Apart from the face, the remainder of the figure is in the form of a wooden carving; specifically, a root carving (a better-grounded term in Polish artistic jargon, to which woodcarving is semantically close). All of the body parts except for the face are almost exclusively created by matching appropriate and unaltered wooden elements; that is, debarked branches, the shape of which can imitate a bent leg or an arm holding a pipe. This three-dimensional representation is complemented by frugal coloring that references local cultural meanings and, as shall be seen, nonetheless performs a significant structural and ideological role.

These methods and techniques and their final effect situate this case of sculptural art within the framework of classically defined folk art. Formally speaking, folk art is characterized by a frugality of themes and composition, schematic forms, categorization of characters, deformations, strong expressions, and a consistency between the form and both the material and the technique (Grabowski 1977: 5-6). The final result is a male figure that measures from several dozen centimeters to natural human height that, again, is familiar to the viewer. He is part highlander, as indicated by his Podhale regional hat with a feather, the pipe he is smoking, his trousers with parzenicas (heart-shaped decorations), and the wide belt that surrounds his waist, and is part bandit, as indicated by his tall bandit hat 


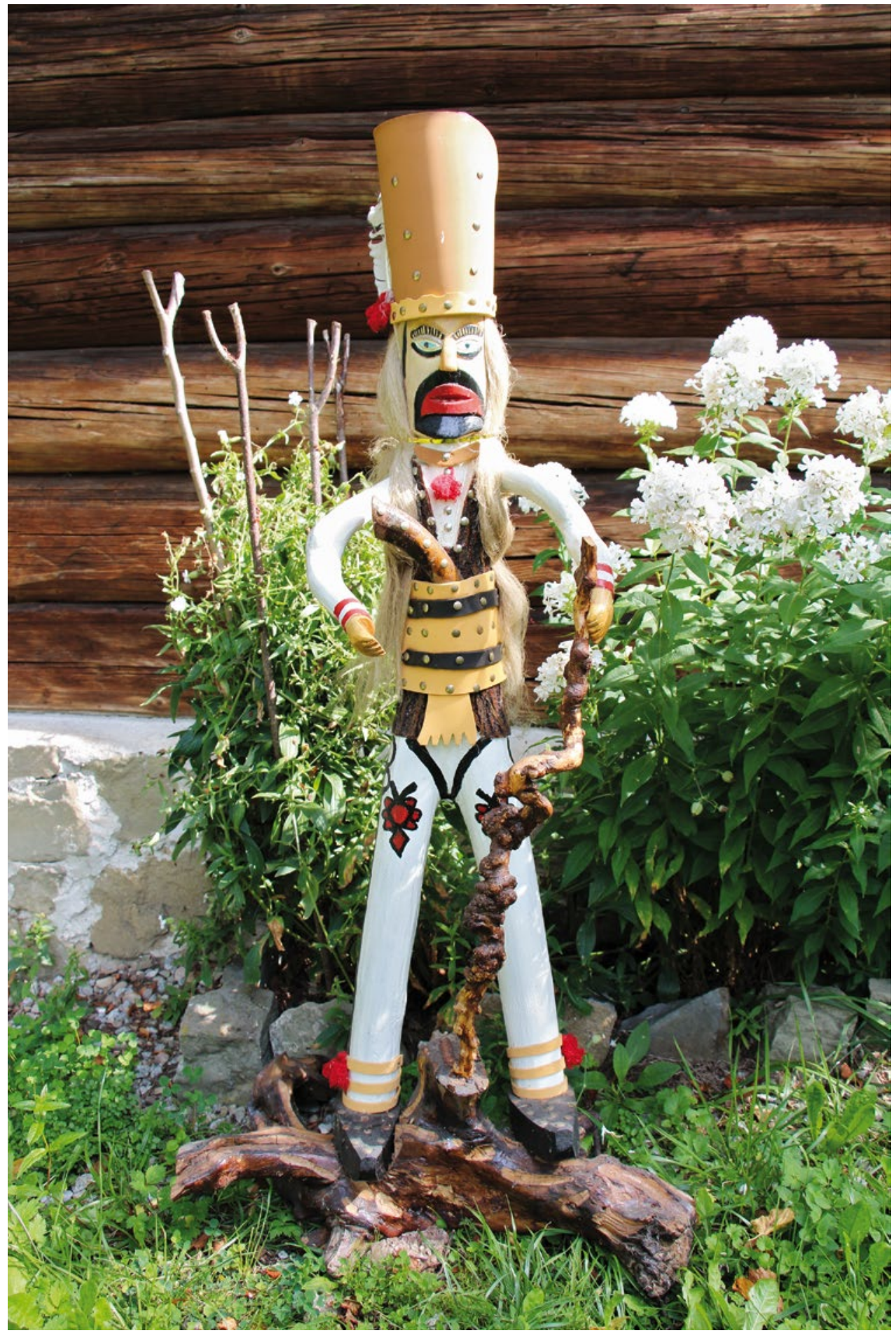

Figure 1: Janosik made by Stanisław Burkat, 2014. Photo: J. Barański. 
and the pistol behind his belt or the ciupaga (shepherd's axe) in his hand. Many of these attributes have been popularized by Władysław Skoczylas's art, but, in this case, one can usually encounter different proportions of these attributes. Moreover, these features cannot be associated solely with the Podhale highlander culture because Spisz, which—despite its strong influences from Skalne Podhale (the part of Podhale west of Spisz)—remains culturally distinct. This also concerns the matter of the local regional dress; specifically, its many varieties stemming from the different villages in Spisz. As a result, the character may not wear white trousers, but may instead be clad in a blue or green vest to resemble the "traditional" Pieniny dress or the local dress in this part of Spisz, respectively. This is also true of the most typical piece of clothing, the hat; thus, in addition to the most popular Podhale version of the hat, one can see a stylized Spisz version sometimes carved on the head of the garden sculpture.

This case can be said to stylistically constitute a peculiar artistic expression that recognizes the heritage of three neighboring regions: Podhale, Spisz, and Pieniny. It is all the more valuable because sculptures of this type are absent in the Spisz canon of traditional folk art. The artist most likely wishes to acknowledge the values of all three regions, which is why his artistic expressions have a unique, supra-regional cosmopolitanism. As a result, he inadvertently carries out Ernst Gombrich's rule of an "adapted stereotype" (1981: 74ff.), according to which the artistic representations of reality that are typical for a given period, environment, and so on are expressed through a stereotypical image of this reality. The final effect, due to the intermixing of elements from different regions, tends toward a supra-regional syncretism.

This choice of expression may seem slightly strange in view of the fact that the "traditions" of the three regions have recently been the subject of thorough, meticulous actions aimed at preserving and separating them in their purest historical forms, lest they disappear. However, it appears that the artist does not consider this preservation of aesthetic purity especially important, nor does he identify with the aforementioned trend for actions undertaken to separate "the chaff from the cultural wheat." Surprisingly, the artist has found an understanding among the recipients of his art, who also seem oblivious to any problem with this local, supra-regional artistic practice that, to a certain extent, conforms to the belief that "anything goes."

Indeed, the wood sculptor perhaps has a reason to undervalue the cultural canons, which are frequently determined by the local proponents of culture, including educated ethnographers. Stanisław Burkat is a resident of Niedzica, despite being born and raised outside the region, and has been creating these sculptures for nearly twenty-five years. His works also include, in his own words, "garden shrines," "eagles standing on their legs," and "hunters," all of which he sells mostly in the Niedzica region, but also outside of it, and even abroad. Burkat (a "yard artist," to use the term coined by Kathleen Condon in 1989) is a keen observer of the local culture, but this does not imply an uncritical adherence to its restrictive rules. 


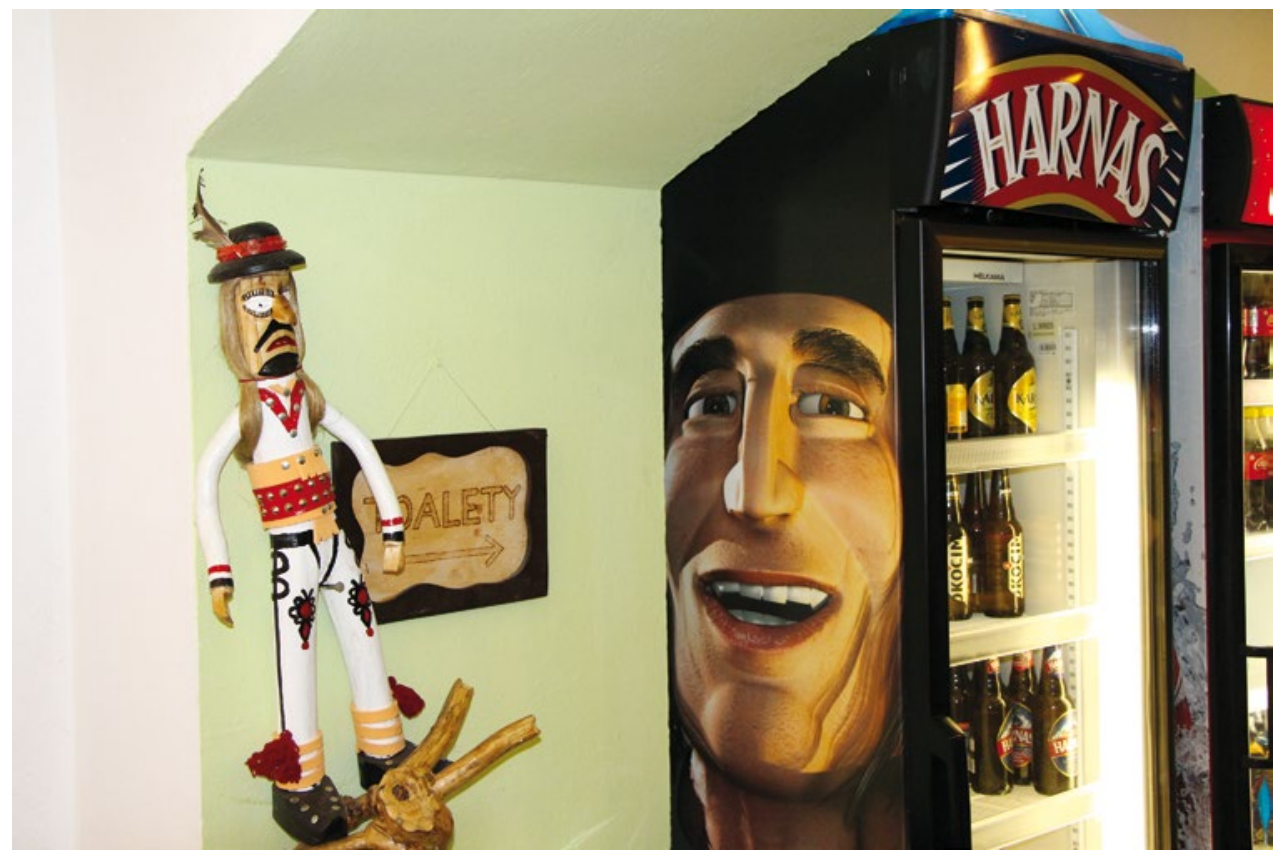

Figure 2: Janosik made by Stanisław Burkat in "Hajduk” restaurant, 2014. Photo: J. Barański.

Furthermore, Burkat's creative inspiration is fed not merely by observing the surrounding world, but also by sources of data that already show signs of significantly processing the information they provide. In this case, the sources of inspiration include television: first and foremost, the 1973 series Janosik, directed by Jerzy Passendorfer. The artist's wife describes her husband's inspiration from the series: "He was watching this series, and he said to himself, 'I think I'm going to make a Jánošík like that one,' and that's how it went. He watched the series a bit, and it went from there." Other residents of the region also confirm the great importance of the series, part of which takes place in Spisz, within the local community: "I remember that, if we were working in the field when the series was on, we'd do everything we could to finish in time for Janosik," a resident of Niedzica reminisced. Indeed, this very specific source of inspiration may have had even further-reaching consequences: a character resembling the muscular protagonist of the series can be seen today in advertisements for the Harnaś brand of beer; not to mention the Hajduk restaurant in Niedzica, which has a beer cooler decorated with a picture of this character (which in fact stands next to a sculpture by Burkat; Figure 2). This local restaurant, frequented by clients from various parts of the country and tourists visiting the attractive Spisz region, is also a meeting place for images that have been created by people from seemingly different domains of public life: an amateur artist and a beer manufacturer.

This is only a rough description of a particular element of the local aesthetic landscape, which includes not only the indicated elements of art brut, but also those of yard and environmental art because the Jánošík sculptures are mainly made from nearly unprocessed 
material that has already been adapted by nature to perform specific visual functions. The Jánošík sculptures often share yard space with the aforementioned gnomes and deer (dioramas of stags in rut), and with universal rustic styles of decoration represented by historical horse carts decorated with red geraniums, or sometimes the cartwheels alone mounted on the walls of former barns, which now serve as garages, in front of which one may notice old wooden troughs that today serve as flower pots. A walk through Niedzica often requires some focus to notice the characteristic figure amid the surrounding vegetation. As exemplified by the local restaurant, one may also find the figure indoors (in this case, inside a public place). I also know of a private household where a Jánošík statue, this time sculpted in the Pieniny style, sits inside on a wooden staircase leading from a sumptuous living room to the second floor of the household.

Undoubtedly, this hero, who is a local element of the outdoor aesthetic, also belongs to the increasingly popular practice of arranging the outdoor environment in a suburban style. This style features mowed lawns, decorative shrubbery, water features, and fountains at the cost of traditional vegetable or flower patches. The whole constitutes a "pretty" or "natural" environment, as the locals often put it, that carries out the newest decorative tendency, which was described by a resident of Niedzica in terms that were somewhat against-the-tide: "We mostly go for novelty." The resident further expressed her longing for the old days, which were dominated by flowers that made everything "look beautiful." Her own garden comprised a lawn, several coniferous shrubs, and a dog and a deer made from plastic. These elements harmonized with her fatalistic and bitter comment about the local state of affairs: "The way it's turned out, it's not nice. Maybe they should cut the flowers, plant trees, make a forest out of the village, and then maybe add some decorations so that at least something shines through in all this."

Let me ignore the ambivalence of the aesthetic experiences that can be seen here on the axes of continuation/permanence, old/new, rural/urban, and so on, and that concern every spot on Earth that undergoes the processes of both continuation and changes of values, ideas and ideals, and earthly and transcendental aims. This ambivalence is expressed through material possessions, which here take the form of popular emblems: lawns, mass-produced garden decorations, prefabricated gazebos, and ready-made flowers in plastic hanging pots. Today, this household dimension seems to constitute the main place for aesthetic expressions, or the "aesthetic locus," to invoke a term used by Jacques Maquet (1986: 69). This is true both inside the region analyzed and outside it. However, in fact, the aesthetic locus changes throughout the ages and among different peoples. In medieval Europe, the locus was the Christian religious ritual and its material attributes: architecture, ritual dresses, sculptures, and paintings. Beginning with the eighteenth century, the aesthetic locus among the European elite was represented by separate branches of art: painting, graphics, sculpture, and architecture. It should be added that, not so long ago, the aesthetic locus in Polish villages was a sumptuous white chamber, in which religious paintings were presented alongside decorative bed sheets, pillows, and rugs, and expressed the owner's familiarity with the beauty of folk art. 
The contemporary popular aesthetic locus (i.e., an appropriately arranged garden) can also be seen outside Spisz, whereas the Jánošík statue, as a decoration, is a local specialty and constitutes an independent challenge to academic inquisitiveness. The aforementioned difficulty with the artistic value of this product in no way precludes the importance of searching for its function. In fact, this methodological directive has constituted the rudiments of anthropological heuristics at least since the time of Bronisław Malinowski, who, even though he was critical of the evolutionary concepts of holdovers (which he understood as dysfunctional cultural elements), rightfully argued that if something exists then it must perform some function. This must also be true in the case of the Jánošík statues, living out their lives in yards (and in other places). The question of whether they can be regarded as art is a separate issue. However, this issue is secondary from the perspective assumed in this article, and I have little difficulty in sharing Evelyn Hatcher's (1986: 8) opinion that art is an idea, not a phenomenon, and thus has no objective reference. In turn, Barbara Kirshenblatt-Gimblett approaches this (essentially terminological) issue in a more detailed manner, stating that anything that gives form to a value can be considered art, including the art of everyday life. At the same time, this form does not necessarily need to meet any criteria of beauty, or involve restoring art to life; nor can one find the art of everyday life in art galleries because everyday life is represented by such things as household interiors, meals, conversations, etiquette, clothing, yards, and parades. As an example of the last of these practices, Kirshenblatt-Gimblett goes so far as to describe the Corpus Christi procession as "performance art par excellance" (Gabik 1995: 417).

Thus, following the example of American folklore studies, one can go beyond the piece of art itself and understand it a separate material object; after all, the example of the Corpus Christi procession—or any other kind of performance—constitutes a practice that is not limited to artistic values, but can also be expressed in terms of social, religious, national, ecological, and other values. In a sense, the case of yard art—being a combination of art brut and environmental art, to name only its most prominent distinguishing features-must represent certain values because its recipients find it appropriate to use the Jánošík statues in their declared decorative function. However, is this their only function? In other words, is one dealing here merely with an object that ascribes a decorative value to its nearest surroundings? It appears that the supposed artistic aspect is only the proverbial tip of the iceberg and that the meaning of the Jánošík statues should actually be sought outside the realm that describes their artistic value. As Mariët Westermann (2005: xiii) notes, the non-artistic surplus in art-which is difficult to discuss and yet impossible not to discuss-is, indeed, the central aspect of art. Hatcher (1986: 201) terms this its "spiritual essence." Furthermore, alongside the artistic value, a much wider field of aesthetic value can exist, which needs to be understood in the spirit of pluralism. Pierre Bourdieu encouraged aestheticians to follow this spirit of pluralism, stating that "working-class people expect every image to explicitly perform a function, if only that of a sign, and their judgments make reference, often explicitly, to the norms of morality 
or agreeableness. Whether rejecting or praising, their appreciation always has an ethical basis” (1996: 5). Therefore, what does a Jánošík statue signify?

In the opinion of Barbara Kirshenblatt-Gimblett, it is significant and necessary for researchers to be situated between different disciplines of knowledge because this allows them to go — in a manner of speaking — beyond a limited viewpoint and instead to observe the studied phenomenon in toto, perhaps as a specific form of art, a manifestation of aesthetic sensitivity, a mythological image, or, finally, a social phenomenon. In fact, all of these constituents can be addressed through a certain synthesizing formula; that is, the aesthetics of everyday life. Kirshenblatt-Gimblett is not alone in her understanding of art as a sensual expression of social values. In addition to Bourdieu's opinion quoted above, other supporters of such an approach include the aforementioned Jacques Maquet. Maquet stated that we primarily live in the world of everyday life, and therefore art should be treated first and foremost as a part of everyday life, rather than only as a specialized world inhabited by artists, critics, and aestheticians (1986: 8). In turn, Stanisław Ossowski wrote the following about the heterotelic understanding of art:

A great part of the universal history of art would belong to the history of other spheres of culture if we were look at it with the eyes of our contemporary milieu. The artistic African, Ceylonese or Polynesian masks arose as the product of magical activity which could form a part of the magician's professional practices, just as did the collecting of plants with poisonous or medical properties . . . . The sculptures of Romanesque cathedrals, the sculptures of Indian and Chinese temples were made by people who were considered just as much craftsmen as were shoemakers or saddlers ... . Masterpieces of art arose before the emancipation of art as a distinct domain of culture took place. (Ossowski 1978: 314-315)

If one were to treat this statement as a potential guidepost and summarize it through the question "What does a Jánošík statue signify?" then the part of the search involving masks - a recurring schematism or even primitivism of the characters, especially of their faces - could become an interpretative pathway towards understanding the art of everyday life. Will one find "magic" here, or a different practice with features of hermeticity, extraordinariness, and mystery? The above definitions should not be treated literally or with the burden of the historical meanings ascribed to them, which prevent the intercontextual application of these definitions. For now, let the notions of "the mask" and "magic" serve as keywords that underline the non-artistic and non-aesthetic functions of the form of creativity discussed because this creativity is more than simply a certain form with a certain content, and possesses more than simply the sum of its sensual, descriptive, and imaginative qualities. However, on the other hand, its meaning also lies in its form and its content, rather than solely in an imagined entity or a general idea (Maquet 1986: 92). In all of this, the mask and magic also constitute categories for referencing the mass reality of humans: 


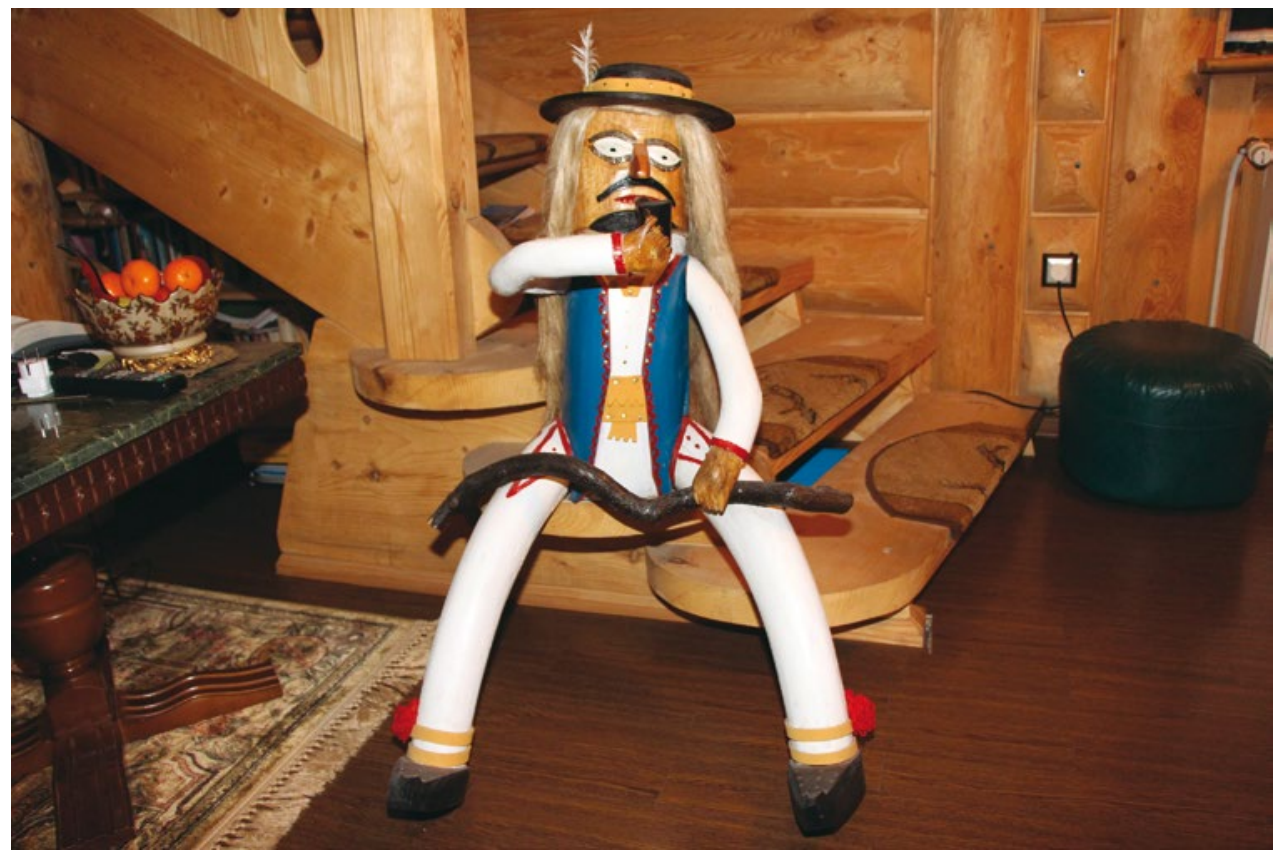

Figure 3: Janosik made by Stanisław Burkat in home interior, 2014. Photo: J. Barański.

shared values, beliefs, imaginings, hopes, and anxieties. Therefore, the provocative question arises: "What is the Jánošík statue the mask of, and what magic accompanies it?" Let the working hypothesis be expressed by the conclusion of Ksawery Piwocki's classic article on amateur art: "Spontaneous art is, first and foremost, ... an artistic documentation of a region, its landscape and inhabitants, and the inhabitants' work" (translation from the Polish edition; Piwocki 1971: 157).

Before going further, in order to satisfy the basic principles of methodology, one should first draw from the empirical evidence; that is, the explanations given by the owners of the Jánošík statues themselves. Among these, there are statements typical to such cases, in which one may suspect the presence of post hoc rationalization: "I thought it was pretty"; "I wanted to decorate my yard"; "It's something different, different from another plastic thing of this kind, something original." These reserved responses should come as no surprise because the possible symbolism of the object is both general and implicit in its character and is rarely expounded in everyday life, and even then such a meaning is exposed through the use of self-verifying terms such as the ones mentioned above. On the other hand, in some cases I received more elaborate answers than the previous, laconic ones: "I like it because it has a bit of a local flavor"; "It represents a bit of this region"; and "People can even learn some elements of our culture from these figures, like the regional dress."

Even though Burkat has clearly crafted the Jánošík statue in the Pieniny style, and even though the figure could be used as a model for at least the regional emploi, its owner still described it as a "little highlander" rather than as a "Pieniny highlander" (Figure 3). 
It is also worth noting that the Jánošík statue is displayed in Niedzica (i.e., Spisz), and not in Pieniny. This means that the owners' descriptions such as "from this area" or "of our region" are inaccurate; however, this not due to ignorance. All of the locals are perfectly aware of the nuances of interregional differences in terms of, in this case, the dress. The prevailing ambivalence does not prevent a final conclusion from being formulated, whereby Burkat's art is a "continuation of our Spisz culture."

The disregard for interregional differences seems to be supported in this case by the terminology. The use of the term góralek 'little highlander' is not coincidental: the object in question is not quite a highlander; it is a cultural hybrid. Although its name comes from góral 'highlander', the Jánošík statue is a somewhat fabricated highlander because the attributes that are emphasized in the sculptures are treated overly selectively and schematically. The figure represents a peculiar, generalized, and fictional highlander, whose characteristics are underlined by the other descriptions: "it has a bit of a local flavor"; "It represents a bit of this regionalism"; and "some elements." This constitutes an example of genre confusion, which nevertheless ultimately leads to the highlander becoming established as an emblem in its own right. Anthony Cohen would likely observe that the Jánošík statue "represents the mask presented by the community to the outside world; it is the community's public face" (1985: 74). This pertains to the outward mission (directed outside of the community) of such a mask. The matter becomes more complicated in relation to the inward direction; that is, the communication taking place within the community through this emblem. As can be seen from the statements quoted, this meaning is slightly different, and "the conceptualization and symbolization of boundary from within is much more complex" (Cohen 1985: 74). However, in no way does this involve any lasting, unchanging symbolic content that would be represented by the original story of Jánošík, Again, as Cohen said: "the form can persist while the content undergoes significant transformation" (1985: 91).

These interpretative clues substantiate the other elements of the owner's aesthetic landscape: a wooden house built in the "highlander style"; the aforementioned locally popular rustic scenography of a household environment (an old plow and a cart overgrown with flowers); lacquered branching tree trunks dug into the ground; and, finally, two plastic life-sized rams and mushrooms growing from (natural!) grass (Figure 4). The whole provides an idyllic and utopian image of the somewhat contradictory will to ultimately establish both a local and an extra-local quality, of culture and nature, and of the old with the contemporary. When asked about what had motivated her to display the two rams in her yard, their owner responded, "I wanted them to remind me of when I used to work on a farm and the rams that my dad used to have, so now I've got rams myself." When asked the same question about the cart, she said, "It reminds me of when I used to ride in a similar cart to get hay when I was a little girl." These are a form of autoethnographic explanations of the entirety of the aesthetic locus analyzed, where all of the elements have been recoded and transferred onto a particular cultural metalevel. The "little highlander," the plastic rams, and the old cart are also the voices of contemporaneity. They share their 


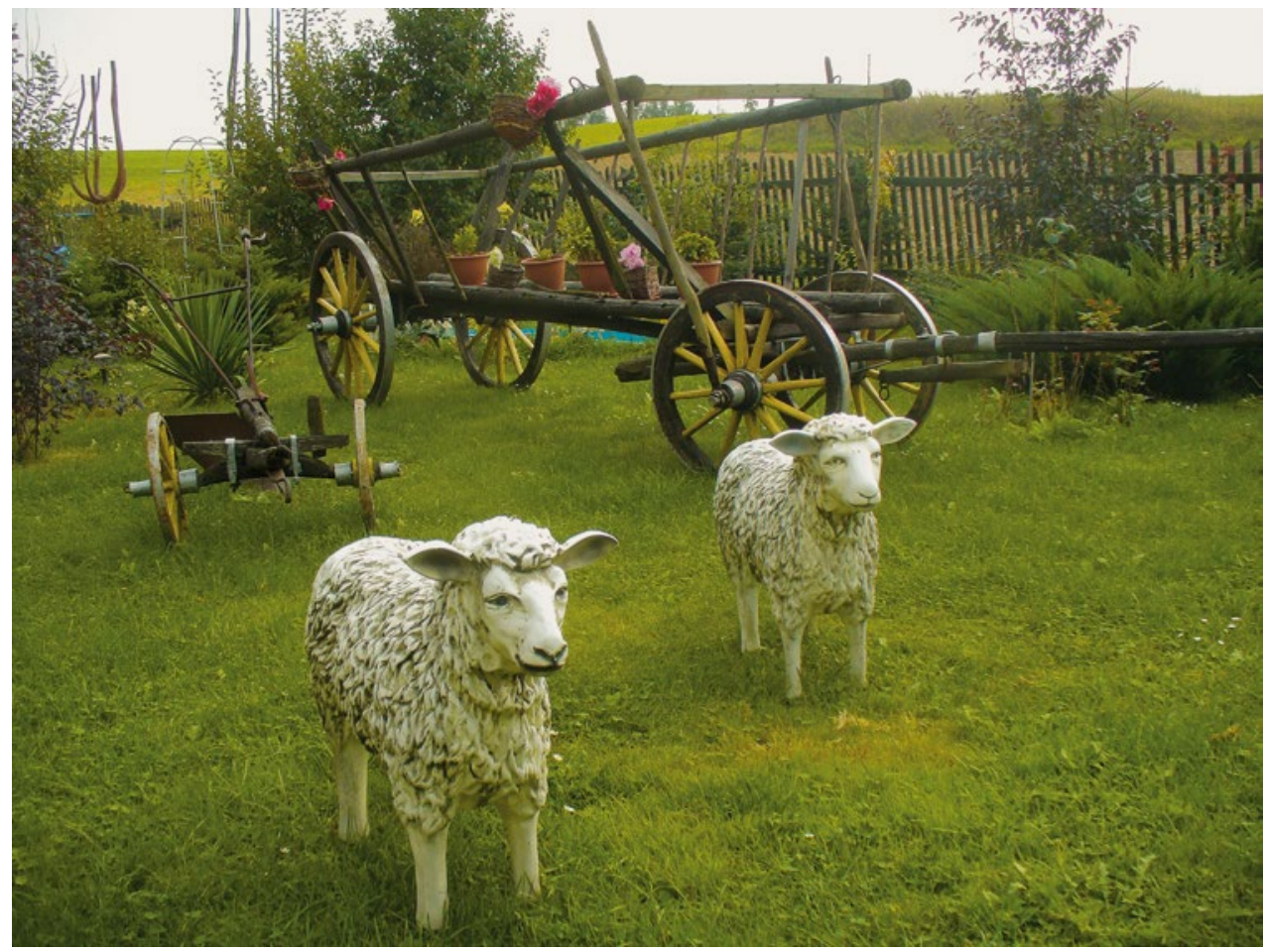

Figure 4: Rustical aesthetics, 2014. Photo: J. Barański.

functions with a plasma television set integrated into the household interior, which is also full of wooden carvings, and with the modern car parked in front of the house.

Such an affirmative approach towards Burkat's sculptures is rare. Opinions can also be heard that are strongly critical of the Jánošík statues, mostly among the "regionalists," as the local proponents of culture-the teachers and the full-time employees of the local department of culture-call themselves. They describe the figures as "not ours" and make statements such as: "I don't like it, personally, it's such kitsch"; "People buy them because they like them, without analyzing them, with no regard for any such associations"; and "For me, [Burkat's] Jánošík is too thin .... He makes all these Jánošík statues look the same ... . I feel as if [the sculpture] does not belong to this region." Here one can witness a telling manifestation of regional pedagogy that ignores the obvious fact that the local population itself has made the Jánošík statue a cultural emblem. In turn, the prevalent "cult of Jánošík" produces trivializing opinions of the image: "I think that the population generally likes brave, manly, and attractive people, and all of these are features Jánošík definitely had."

Having quoted the opinions of "the regionalists" on the local social scene, I also provide their views on other elements of the aesthetics of everyday life. The guardians of local culture also disapprove of the plastic, mass-produced garden decorations: "All of these plastic things — definitely no. I personally find it funny and awkward when I see a zoo in someone's yard." On the other hand, they admire the aforementioned rustic style; that is, 
the various types of cultural waste from previous periods that embody "tradition": "An old barrel of sorts," "Sage, and flowers planted all over a cart. That's my style." Objects of this kind are regarded in this environment as representatives of the local heritage that are worthy of presenting and displaying. One may call these objects particular cultural distillates, which either have an aesthetic value or have become imbued with such a value; for instance, by being placed among a flower display or through rudimentary conservation work; that is, being cleaned and painted with transparent lacquer. This form of spectacularity can also be observed in the plays of ritual theatre (e.g., at regional festivals such as Spiskie Zwyki or Spiska Watra), which I address more fully later. Ritual theater is the site of cultural distillation, involving a process that has been completed perfectly, with (it should be added once again) an emphasis on the aesthetics of presentation.

This outline, both aesthetic and selective, of the residents' attitude toward their local cultural heritage is accentuated by a comment from a regional activist: "The world of today is different. We can't go back, so we just want to take from our ancestors, from our greatgrandfathers, what has been developed; we want to take the things that are beautiful and that we like and, in truth, respect." It is in this dimension, often exhibited through festivals, that the regional dance groups in Spisz representing different ages are proud to demonstrate the effects of their choreographic, musical, and dramatic work, carried out under the careful supervision of the "regionalists." It is also the "regionalists" that complain about the "erasing" of local "tradition" while at the same time underlining the need to "implant" this culture. "Through Spiskie Zwyki we can teach a whole generation," as an exponent of "regionalism" observed. Another supporter admitted that she personally experiences a deep connection with her local heritage: "When I put on regional dress, I feel more attached to this region. I begin to feel proud of belonging to this community."

However, a representative of the local elites, albeit not a member of the "regionalist" movement, stated that, even though these cultural enterprises are greatly popular, "The larger population is a fairly silent participant in these events, which mostly pass unnoticed, I think; the majority of the population is not interested." He added: "People's opinions on the subject are so undeveloped that they are indifferent about it — they are neither happy nor critical of it"; and "Society is indifferent to the ideas and the historical aspect ...., though they like the entertainment. Further, this is the main aim of these events: to have good fun." These remarks were confirmed by the opinions of some "ordinary" residents about these initiatives, who said things such as "I have nothing to do with it." A regional activist also said that he had received bitter comments from part of the older generation about his passion for collecting historical artifacts, expressed through the statement: "What do you need this garbage for?"

These responses confirm Józef Burszt's opinion provided many years ago about tradition being restored "mainly for the purposes of cultural consumption" (1974:335-336). At the same time, however, the opinions show that there is an acceptance of the local tradition, which ultimately eliminates the mythologizing aspect from it. Avoiding this aspect 
is difficult, as is evidenced by the responses quoted above, which are filled with various clichés, emotions, and convenient generalizations. A relatively unstructured description and an optimal understanding of the cultural landscape discussed require precise observations that focus on the details of the reality analyzed while it undergoes the processes of both continuation and change. These processes are the object of emotional attitudes, such as conflicts over the "authenticity" of the cultural content fostered and the form and range in which it is preserved and relayed. This cultural content is the subject of reflection from the very actors that are engaged in the regional cultural scene because the "regionalists" include not only relatively young supporters with a university education, but the older generation as well. Many persons aspire to be a "judge of normality," as Michel Foucault (1998: 368) calls those that enforce the normative power. However, the differences in age, education, and experience also generate differences in each person's attitude toward local heritage.

This fact is acknowledged by the young generation of regional activists themselves. They admit that they sometimes come across critical responses to particular elements of their regional dress, or to the script of a ritual scene played during a local festival, or the lines of a song: "There are people over eighty who come to Spiskie Zwyki .... Sometimes, someone's uncle or aunt comes, and says, 'You've done very well, but I remember that it used to look [different],"' said a regional activist. This also concerns the situations that take place outside (in the literal sense of the word) the theatrical stage. On their way to church, girls wearing regional dresses were approached by elderly women, who pointed out deviations from the traditional dress, such as the girls' calf boots, which according to the older "aunts" should instead be "celebratory heeled shoes." Although such remarks sometimes lead to corrections in the script or dress and an investigation into "what it should really be like," they do not completely remove the discrepancy between the real past and the theatrical present.

To illustrate this, let me quote a remark from a senior member of the community, who invited me to visit a private regional museum he had established. He described the items on display: "There you can see a pair of regional trousers, which people used to wear here in Niedzica in Spisz. This is a man's coat of the type people wore in our parts. And here are women's shirts and a vest. But today, when I look at what people are wearing, it's all been changed. It's not like it used to be any more .... It's all gone now." At the same time, he admits that these changes that contradict the heritage especially concern, in this particular case, male dress. Generally speaking, while he acknowledged the efforts on the part of the regional activists, he held the bitter opinion that "If things continue this way, then it'll be almost as if people want the young generation to forget what it was like in the past on purpose." Another member of the same generation noted that the "regionalists" draw information from "books in which people are asked about things" as opposed to drawing information from what "is real."

Having reviewed the various attitudes that exist toward local heritage and related emotions, cultural competence, and historical knowledge, it is time to establish certain 
generalizations that will allow for particular approximations in the understanding of the Jánošík phenomenon in Spisz. This "larger look" at the wider context of the regional, or even supra-regional culture, is necessary to notice more than the proverbial tip of the iceberg. The tip is made of — described here somewhat selectively—-the titular Jánošík statues displayed in the yards in Niedzica, as well as the menagerie of mass-produced plastic or cement animals, occasionally complemented by shining and blinking Christmas decorations, rustic attributes of past culture, and, finally, the artistic forms represented by regional folklore: music, dance, and ritual theatre. All of these cases involve a clear visual aspect, the rules of which enforce a combination of selectiveness, spectacularity, and, in more general terms, aesthetics. The yard part of this aesthetic locus is an everyday sight, which makes it gradually become common, as opposed to the cultural events and religious ceremonies in which the actions on stage, and especially regional dress, attain an uncommon and solemn rank. These ceremonies become a significant affirmation of local heritage, an expression of the participants' and the audience's connection with the region, and an incarnation of a regional identity, even if they simultaneously constitute a regional flagship event and a tourist attraction (Figure 5).

Interviews with the locals (i.e., the creator of the Jánošík statues and his clients), as well as with the regional activists and "ordinary" residents, indicate that the regional cultural heritage of Spisz-including its content, range, character, degree of continuity/ changeabilty, and, lastly, its role in shaping the contemporary image of the region and its residents—are viewed in a considerably varied manner. A particular role is played here by the Jánošík statue, which is an intriguing figure that draws attention owing to its aesthetics, iconography, and sculpting technique. It is terrifying and grotesque; however, at the same time, its solemn appearance makes it an ambivalent and challenging character that introduces an element of anxiety. According to Hatcher, anxiety is characteristic of art that performs the function of gauging different social tensions. The goal of art, after all, is to maintain an equilibrium between what is unitary (emotions), social (structure), and cultural (symbols) using forms that constitute, in essence, collective representations; and it is thus that art can display relatively permanent artistic values. A new form appears only when the equilibrium is disturbed. Examples of this phenomenon can easily be found in various acknowledged avant-garde movements, including the titular case of artistic creation (Hatcher 1986: 163-164). This state of disturbed equilibrium is frequently referred to as a crisis. There is ample evidence that such a crisis, as a logical consequence of changes in the contemporary cultural dynamic, can be found in the opinions on the different subjects quoted above; these are opinions that are undeniably diverse and are sometimes even contradictory.

Tensions can be observed (or perhaps, heard) in the aforementioned responses. In fact, the responses can be generally divided in a manner that, to some extent, reflects the social divisions in terms of a given group's attitude toward the regional heritage. The first group of participants in the local (not necessarily explicit) cultural debate comprises 


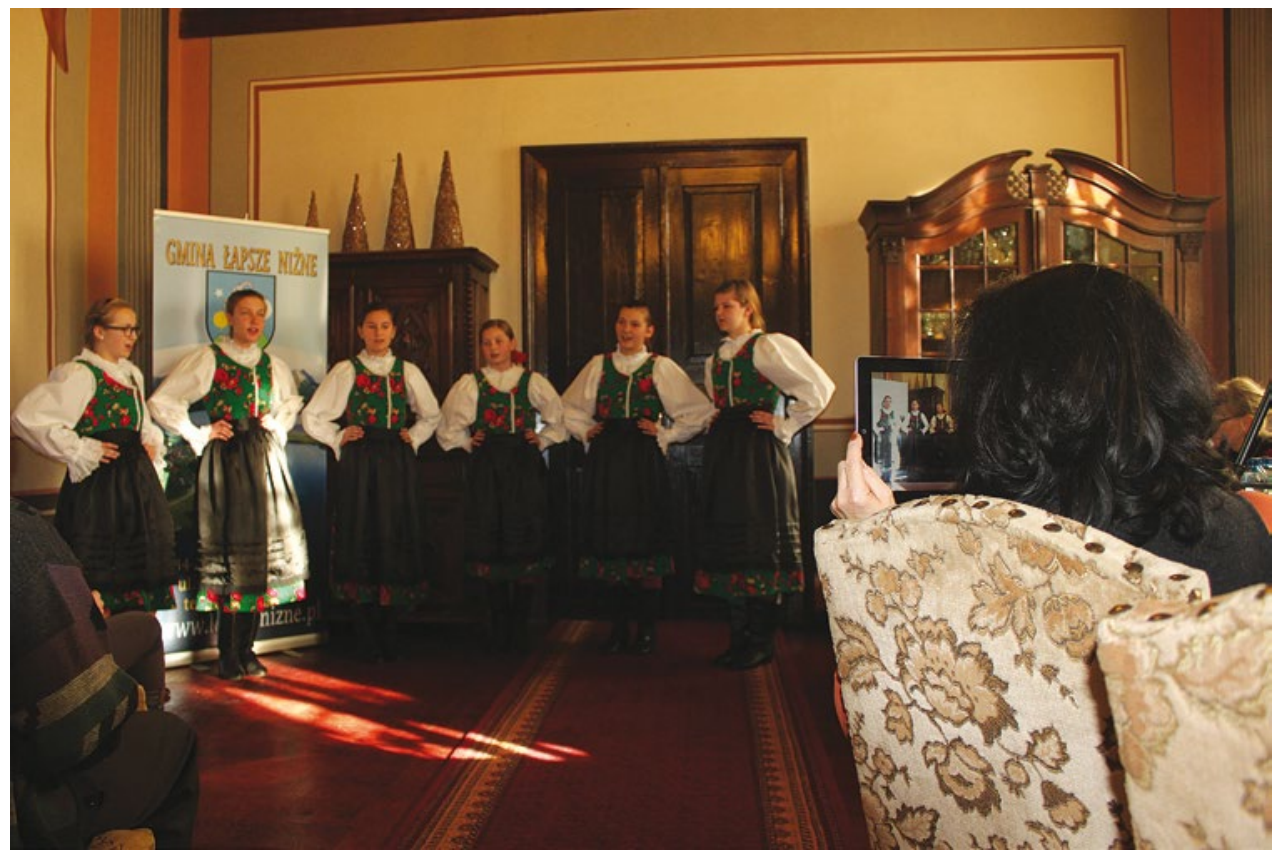

Figure 5: Spiskie Zwyki folklore festival, 2014. Photo: J. Barański.

the "regionalists," or the small circle of guardians and lawgivers, who have built up their authority based on their social capital (primarily their education) and their passion for the local culture. Following Ryszard Tomicki, the group's attitude can be considered prospective traditionalism, which restores and standardizes cultural heritage and uses the (implicit) notion of describing the present from a future perspective: "We can't go back, so we just want to take from our ancestors, from our great-grandfathers, what has been developed; we want to take the things that are beautiful and that we like, and, in truth, respect." The second group is also small and comprises the guardians and witnesses; that is, the eldest representatives of the community, whose knowledge of heritage comes from their own memory. Their attitude can be associated with secondary traditionalism, which manifests itself as resistance against new forms and as descriptions of the present from a past perspective. Finally, there is a third group comprising the greatest number of local inhabitants, which may be called the "indifferent" group. Its members follow the "I have nothing to do with it" maxim. Although its members participate in fairly large numbers in the regional cultural events, they do so only on special occasions, in harmony with the annual cycle that is established by the local authorities.

The representatives of the first two forms, or of traditionalism, constitute a minority within the community analyzed. However, can the fairly silent and indifferent majority be ascribed to any model or category under the object-based understanding of tradition? Tomicki's model also takes into account what is referred to as integral tradition (Tomicki 1981: 362); albeit in his case the term was used to describe a historical rural community 
(from the end of the nineteenth century and beginning of the twentieth century), which makes the subjects less analogous. However, if the term were devoid of its function of hypostasizing a particular historical case of a local culture, then this integrity could be understood more broadly as the freedom from problems, familiarity, normality, immanence, or even the naturalness of the attitude not only toward one's own narrowly defined and somewhat artificially distinguished heritage, but toward any cultural concretions at all. Such an integral tradition is an unrestricted, unforced, reflectionless, grassroots, and dynamic attitude—devoid of the ideological component, although not free from axiology — towards different coexisting content. In this way, an old horse cart may find a common denominator with a yard sculpture inspired by a local legend (the Jánošík sculpture), a plasma television set (because television sets have been in use in Polish villages for decades), and plastic rams (after all, they are a "variety" of the real ones).

In fact, the owners of the Jánošík statues, who frequently praise Burkat's art, are almost exclusively representatives of the third group described above, which can be considered part of the integral tradition. These peculiar wood sculptures cannot be found in the yards or the houses of the two groups of guardians; they are not found among those that only follow the aestheticized layer of the local culture, nor are they found among those that are accustomed to everything that passes. Both groups openly disapprove of this local "kitsch," which they find to be more of a defacing of the aesthetic landscape than a decoration, an obstacle rather than an aid, and a reason for shame rather than for pride. It seems, however, that the intriguing form and style of the sculptures in combination with the mythologizing content they relay make them (on a local scale) a unique case of an artistic provocation that is inextricably linked to a different form of collective awareness. This provocation is a response to several conflicting qualities: history and legend, regional and supra-regional awareness, Polish-ness and Spisz-ness, sanctity and commerce, and folklore and pop culture. It is also notable that the local population approves of Burkat's art, which is manifested in the fact that the residents buy his Jánošík statues and display them with great solemnity, mainly in the form of yard art. Placing an art piece in such a position has always been, according to a view shared by various experts (e.g., Olęcki 1970; Grabowski 1976), a sign of the authenticity of folk art, which sprouts directly from its local roots. Perhaps Burkat's art is a contemporary example of spontaneous inspiration that is shared within the environment of its artistic inspiration, or an example of folk culture returning in its former shape, especially because its proponents are not the influential representatives (the guardians), but are instead "run-of-the-mill people."

Regardless of whether this thesis is justified or not, understanding the function of the art analyzed requires referencing non-artistic and non-aesthetic correlates, within which the meaning attains a systemic character that is encoded in multiple manners; in other words, one must reference the entire cultural sphere, as Jan Białostocki (1980) put it. The archetype (the cultural hero) is an element of a certain microcosm that binds the imagination of both the artist and the recipient, through what Maquet (1986: 158) calls spiritual communion, and 
what Jack Hobbs (1975: 179) calls the personality of a society; that is, the hero embodies the social ideals. All of this forms a particular "us," or an objectified outline. "Here, [the artist] has revealed something about Spisz, something about its atmosphere. He shows something about the region," as the owner of "Jánošík the Little Highlander" commented. It is now clear that this "something" confirms the syncretism of the iconography that makes up its character. In the social dimension and in the context of the respondents' statements, this correlates with a feeling of standing at a crossroads, with feelings of uncertainty about the future cultural path. Nonetheless, this fact does not prevent the mythologizing process from being present, in which the iconic representative of a cultural hero embodies the particular local social ideals, which are vibrant and are desired.

The Jánošík statues seem to function as ideograms, as a common ancestor and a particular totem that supports group identification. At the same time, they are elements of the community's genius loci. Perhaps the terminological network of the "mask" and "magic" mentioned in passing at the beginning of this analysis adequately reflects the reality studied. After all, a mask is a peculiar object, which is displayed outside and sometimes inside a household, whose ideological message extends beyond the household and its residents, and seemingly encompasses a vast cultural area. Magic constitutes the actions and narrations that inseparably accompany the mask. In various proportions, these actions and narrations may be manifested in the standardized local culture, which is installed in independent regional museums and represented by regional artistic groups. However, they can also be manifested in declarations such as "We mostly go for novelty." This entire complex of cultural narration forms a particular nascent ethos that, as Geerz (2005: 111) would put it, represents a social group. It then becomes a venue for the spontaneous policy of intra- and intercultural differences, and the various elements that make up the group's identity undergo the processes of fading and adaptation, continuation and change, and strengthening and weakening.

These conclusions leave no room for doubt that the Jánošík statues are more than simply a conscious expression of particular aesthetic beliefs. At a deep level-the level of mass unawareness, so to speak - they occupy the very center of an intense identity-building process that is taking place. They are also a manifestation of the recurring question (especially in the age of dynamic cultural changes) and more general question: "Who am I: a Pole, a Spisz resident, a highlander, or perhaps a Slovak?" From a more detailed perspective, the answer to this (not necessarily explicit) question predominantly takes the form of the particular cultural practices, and constitutes evidence of the ambiguousness and growing role of hybridization in the regional identity, which is becoming a node comprising multiple elements. Hybridization of this identity is accompanied by a process through which the local heritage becomes the subject of reflection, discourse (Lubaś 2008: 42), various adaptations, or even disputes over its value. In this case of practiced auto-ethnography, a stereotype of a highlander culture is what is perhaps ultimately created; that is, a generalized image of what being a highlander entails. Nonetheless, this image continues to return to its place of 
origin (albeit in a slightly altered form): for instance, the muscular character from the beer advertisement or the mythical representations of highlanders in the minds of tourists visiting the area. Thus, through the culture of tourism, the emblems of the local culture, which are frequently recoded and included in a wider, supra-regional movement, reinforce that local culture, making it the object of thematization, musealization, and commodification.

Certain divisions can be made within the range of the aforementioned complex and multidimensional tendencies. Namely, the regional culture in its traditional aspect, represented by the guardian-lawmakers and the guardian-witnesses, has a tendency to be solidified in the form of a particular, finite set of themes, motifs, and styles. These are frequently manifested emblematically as folklore-based ornaments (Krajewski 2005: 85), which become further immobilized in a particular model as an essentialized (Lubaś 2008: 42) and reproducible form, and which sometimes also become a market commodity. This type of regional culture may be termed relatively closed. In turn, the regional culture in terms of its integral aspect- the culture that combines the Jánošík statues, nostalgic traces of the bygone culture, and attributes of modernity-appears (in contrast to the previous type of regional culture) to be relatively open, with an additional, noticeable tendency for the supra-regional merging and adaptation of content from other cultures. In the latter case, one also encounters a tendency to abandon the idealized local forms and content of regional culture in favor of a more general form of highlander culture that encompasses a number of regions and is represented by, among other things, the titular character. Both cases form unique sub-worlds, which, despite their differences in attitude toward the cultural heritage, share some of the content, especially the local dialect, which is still very much alive. Among the elements of cultural difference understood in this way is the return to the identity stage of an archaic cultural hero that, by force of the supra-regional sensus communis, fills a certain vacuum in the regional identity.

The last conclusion does not aim to make the Jánošík statue a clear sign of the local community, nor is it a cultural panacea for the shortcomings of the local culture, which has difficulties with combining the old and the new. This is because cultural change unavoidably leads to the breaking, shifting, and disappearance of historical content, which is replaced with adapted or alien content. The spectacular case described above, of restoring the hero myth in the form of a peculiar wooden sculpture, is (as should once again be underlined) merely an external symptom of particular tectonic movements in a collective identity. At the same time, the sculptures express the need for unambiguity, permanence, and cultural certitude. Barbara Szacka puts it well when discussing the relationship of the past, memory, and myth: "Historical characters and events lose their ambiguity and are transformed into one-dimensional symbols of values that are important for the life of a group; and the matter-of-fact accounts of these characters and their values are replaced with emotional tales" (2006: 24). Jánošík, who is otherwise a completely historical character, functions within the culture nearly exclusively as a mythological hero, who transcends even the national ethos and is part of a local group's wider ethnological image (Appadurai 
2005). Although the myth of Jánošík has lost its character of a linear spoken or written narration, it still finds expression in the seemingly banal iconography of his image from the realm of yard art, which is actually rich in content and meaning.

\section{REFERENCES}

Appadurai, Arjun. 2005. Nowoczesność bez granic. Kulturowe wymiary globalizacji. Transl. Z. Pucek. Krakow: Universitas.

Balara, Michał. 2013. Spiski kotlik dukatów. Gawędy ludowe. Krakow: Astraia.

Białostocki, Jan. 1980. Historia sztuki wśród nauk humanistycznych. Wrocław: Ossolineum.

Bourdieu, Pierre. 1996. Distinction: A Social Critique of the Judgement of Taste. Cambridge: Harvard University Press.

Burszta, Józef. 1974. Kultura ludowa - kultura narodowa. Warsaw: LSW.

Cohen, Anthony. 1985. Symbolic Construction of Community. New York: Routledge. DOI: $10.4324 / 9780203131688$.

Condon, Kathleen. 1989. “Learnin', Though”: Environmental Art as a Creative Process. In: Daniel Patterson \& Charles Zug III (eds.), Arts in Earnest. North Carolina Folklife, pp. 179-191. Durham: Duke University Press. DOI: 10.1215/9780822381617-011.

Foucault, Michel. 1998. Nadzorować i karać. Transl. T. Komendant. Warsaw: Fundacja Aletheia.

Gablik, Suzi. 1995. Conversations before the End of Time. Dialogues on Art, Life \& Spiritual Renewal. Available at: www.nyu.edu/classes/bgk/web/gablik.pdf, accessed June 11th, 2012.

Geertz, Clifford. 2005. Interpretacja kultur. Wybrane eseje. Transl. M. Piechaczek. Krakow: Jagiellonian University Publishing House.

Gombrich, Ernst. 1981. Sztuka i ztudzenie. O psychologii przedstawiania obrazowego. Transl. J. Zarański. Warsaw: PIW.

Grabowski, Józef. 1976. Dawny artysta ludowy. Warsaw: LSW.

Grabowski, Józef. 1977. Sztuka ludowa. Charakterystyki-porównania-odrębności, Warsaw: Wydawnictwa Artystyczne i Filmowe.

Hatcher, Evelyn. 1985. Art as Culture. An Introduction to the Anthropology of Art. New York: University Press of America.

Hobbs, Jack. 1975. Art in Context. New York: Harcourt Brace Jovanovich.

Krajewski, Marek. 2005. Kultury kultury popularnej. Poznań: Adam Mickiewicz University Press.

Lubaś, Marcin. 2008. Tradycjonalizacje kultury. O zaletach i ograniczeniach koncepcji "tradycji wymyślonych.” In: Grażyna Kubica \& Marcin Lubaś (eds.), Tworzenie i odtwarzanie kultury. Tradycja jako wymiar zmian spotecznych. Studia $z$ dziedziny antropologii spotecznej, pp. 33-70. Krakow: Jagiellonian University Publishing House.

Maquet, Jaques. 1986. The Aesthetic Experience. An Anthropologist Looks at the Visual Arts. New Haven, CT: Yale University Press.

Olęcki, Jacek. 1970. Sztuka Kurpiów. Wrocław: Ossolineum. 
Ossowski, Stanisław. 1978. The Foundations of Aesthetics. Boston: D. Reiter Publishing Company. DOI: 10.1007/978-94-009-9766-0.

Piwocki, Ksawery. 1971. Artyści dnia siódmego. Katowice: Śląsk.

Szacka, Barbara. 2006. Czas przeszty, pamięć, mit. Warsaw: Scholar.

Tomicki, Ryszard. 1981. Kultura - Dziedzictwo - Tradycja. In: Maria Biernacka, Maria Frankowska, \& Wanda Paprocka (eds.),Etnografia Polski. Przemiany kultury ludowej, vol. 2, pp. 353-370. Wrocław:

Ossolineum.

Westermann, Mariët. 2005. Introduction. In: Mariët Westermann (ed.), Anthropologies of Art, pp. vii-xxxi. New Haven, CT: Yale University Press.

\section{AMATERSKA UMETNOST IN SODOBNA REGIONALNA IDENTITETA PRIMER POLJSKEGA SPISZA}

V razpravi avtor obravnava vlogo amaterske umetnosti lokalnega kiparja Stanisława Burkata med transformacijo regionalne identitete prebivalcev poljske pokrajine Spisz (slovaško: Spiš). Njegove skulpture narodnega junaka Janošika učinkujejo kot ideogrami, kot znak skupnega prednika ali totem. So elementi genius loci v skupnosti. Obenem ti kipi niso le zavesten izraz posebnih estetskih prepričanj, temveč na globoki ravni množičnega nezavedanja pričajo o intenzivnem procesu vzpostavljanja identitete in hkrati manifestacijo nenehnega spraševanja: "Kdo sem jaz? Ali sem kot prebivalec Spisza Poljak ali Slovak."

Umetnost Janošikovih kipov tako v sebi združuje nostalgične sledi pretekle kulture in značilnosti modernosti, ki je v nasprotju s preteklo regionalno kulturo relativno odprta, s težnjo po nadregionalnem združevanju in prilagajanju vsebin iz drugih kultur. V slednjem primeru je značilna težnja po opustitvi idealiziranih lokalnih oblik in vsebin; hkrati je pomemben poudarek na bolj splošnih oblikah visokogorske kulture, tipične za več pokrajin. Ti primeri kažejo na edinstvene svetove, ki si kljub razlikam v njihovem odnosu do kulturne dedišcine, delijo številne elemente, še posebej zelo živo lokalno narečje.

Janošikov kip kljub temu ni docela razviden in prepoznaven znak lokalne skupnosti, prav tako pa tudi ne pomeni rešitve za težave kulture, ki bi rada združevala staro in novo. Upodavljanje junaka in obnavljanje junakovega mita v obliki značilnih lesenih skulptur je v veliki meri zunanji simptom tektonskih premikov v občutenju kolektivne identitete; a hkrati prav ti kipi izražajo potrebo po nedvoumnosti, trajnosti in gotovosti.

Dr. Janusz Barański, Jagiellonian University, Institute of Ethnology and Cultural Anthropology, Krakow, Poland, j.baranski@iphils.uj.edu.pl 